\title{
Determinants of Demand for Theatre Tickets in Austria and Switzerland
}

\author{
Marta Zieba \\ Trinity College Dublin, Ireland
}

\begin{abstract}
This paper presents a short, comparative analysis of the determinants of theatre attendance using a novel panel data set for Austrian and Swiss non-profit theatres. The results of the econometric analysis suggest that price and income have significant effects on theatre attendance, the first effect being negative and the second positive. However, both price and income elasticities are not greater than one in absolute values. This reinforces the findings of previous studies on the determinants of demand for theatre. Furthermore, the results indicate that total theatre capacity and in some cases objective output characteristics are also important determinants of attendance, in line with some previous studies.
\end{abstract}

Zusammenfassung: Dieser Artikel stellt eine kurze, vergleichende Analyse der bestimmenden Faktoren für Theaterbesucherzahlen dar, bezogen auf neue Paneldaten für Österreichische und Schweizer gemeinnützige Theater. Die Ergebnisse der ökonometrischen Analyse deuten darauf hin, dass der Preis und das Einkommen signifikanten Einfluss auf den Theaterbesuch haben, der erste Effekt wirkt negativ und der zweite positiv. Jedoch sind sowohl Preisals auch Einkommenselastizität nicht größer als eins in absoluten Werten. Das bekräftigt Erkenntnisse früherer Studien über die bestimmenden Größen für die Theaternachfrage. Außerdem zeigen die Resultate, dass die gesamte Theaterkapazität und in einigen Fällen die objektiven Output-Eigenschaften auch wichtige bestimmende Faktoren für die Besucherzahl darstellen, was mit einigen bisherigen Studien übereinstimmt.

Keywords: Demand for Theatre, Price and Income Elasticities, Panel Data, Austrian and Swiss Theatres.

\section{Introduction}

This paper presents a short, comparative econometric analysis of the determinants of theatre attendance using data for Austrian and Swiss non-profit performing arts institutions. The aim of this research is to provide estimates of price and income elasticities of demand for theatre tickets. Furthermore, this article will test the effects of total theatre capacity and objective output characteristics on attendance. This is the first empirical study of this kind which examines the determinants of demand for theatre using a panel data set for 20 Austrian theatres for a period of 36 yearly theatre seasons and 25 Swiss theatres for 26 yearly theatre seasons. This data set has been extracted from the yearly issues of the statistical reports Theaterstatistik published every year by the German Stage Association (Deutcher Bühnenverein). In order to estimate the demand function for theatre, 
the fixed-effects model with autoregressive component is applied. The variables entering the model follow closely the specification used by O'Hagan and Zieba (2010) where the determinants of demand for German public theatre were examined. The main motivation of the article is to confirm earlier findings that the performing arts are a normal good but demand for theatre tickets is price-inelastic. Additionally, the findings confirm the hypothesis that the output characteristics variables which describe the objective quality of the artistic performances have also a positive and significant effect on theatre attendance.

The article is structured as follows. Section 2 introduces shortly the theatre sector in Austria and Switzerland and presents the data sources used in this study. Section 3 outlines the econometric model used together with the description of the relevant variables. The descriptive statistics and the empirical results are discussed in Section 4. Section 5 concludes the paper.

\section{Data Sources}

Panel data for theatres in Austria and Switzerland are constructed using the annual Theaterstatistik (theatre statistics report) which has been published each year by the German Stage Association since 1965. By far the largest part of this report is assigned to data for German public theatres, but data for Austrian and Swiss non-profit theatres are also included. Data on Austrian theatres were included for the first time in Theaterstatistik 1969/70 and data on Swiss theatres in the 1979/80 report. The main aim of Theaterstatistik is to simplify and unify the statistical data for public theatres. The layout of Theaterstatistik has also not changed substantially since 1965 which enables comparison of data both over time and between the two countries. ${ }^{1}$ Using Theaterstatistik as the main data source, unbalanced panel data are collected for 20 Austrian theatres for the period 1969/1970 - 2004/2005 (545 observations) and for 25 Swiss theatres for the period 1979/1980 - 2004/2005 (430 observations). Among Austrian theatres, 13 theatres are located in Vienna including four large federal theatres (Bundestheater) and also large private theatres. Among 25 examined Swiss theatres, 13 theatres are located in the French-speaking and 12 theatres in the German-speaking part of Switzerland. ${ }^{2}$

Austrian and Swiss non-profit theatres have a very similar institutional structure which enables valid comparison of the empirical results obtained for both countries and also comparison of the results obtained for German theatres in other studies. Similarly to German public theatres, both Austrian and Swiss non-profit theatres gain their revenue on the market through the tickets sales but they can only meet a fraction of their production and running costs. Based on the data used in this study, the level of subsidies accounts on average to 71 per cent of the total theatre budget for Austrian theatres and to 66 per cent for Swiss theatres. In contrast to the theatres in Austria and Germany where legal state ownership is predominant, the theatres in Switzerland are publicly financed but not run as

\footnotetext{
${ }^{1}$ Data on Austrian and Swiss theatres are listed in the Theaterstatistik in the same way every year. Hence, comparison of data over the yearly theatre seasons is possible. With regard to data composition and content, the statistical tables for Austrian theatres also correspond with those for Swiss theatres.

${ }^{2}$ There are also six Gastspielhäuser located in the German-speaking part of Switzerland which are however engaged in festivals productions only and these theatres have been excluded from the following analysis.
} 
state cultural institutions governed by laws applying to public institutions (Kotte, 1998). Furthermore, the financing through private donations and sponsorship are not relevant for both Austrian and Swiss theatres (see Gruber and Köppl, 1998). ${ }^{3}$

As it is also the case in Germany, Austrian and Swiss theatres are organised as multibranch theatres, meaning that they produce different art genres (i.e. opera, operetta, musicals, drama, youth theatre and classical concerts). Most of the theatres examined have also their own venues and artistic management. There are, however, some differences with regard to the employment of full-time artistic staff. Whereas both Austrian theatres and German-speaking Swiss theatres employ staff, including artists and ancillary staff (technicians and administrators), the established theatres in the French-speaking part of Switzerland (except the Grand Théâtre de Genéve) do not employ the artistic ensemble on a full-time basis. These theatres remunerate their foreign ensembles on a per-production basis.

\section{Econometric Model and Variables Used}

In this section the econometric model of the determinants of theatre attendance and the description of the variables used are presented. The demand functions are estimated separately for Austrian and Swiss theatres using an unbalanced panel data for every theatre $j$ and yearly season $t$. Furthermore, due to the difference in the employment structure discussed earlier, theatres in French-speaking and theatres in German-speaking part of Switzerland are analysed both together and separately as independent samples.

Following O'Hagan and Zieba (2010), it is assumed that theatre attendance depends on admission price, income, total theatre capacity and a number of objective output characteristics. Most of the data are fitted using the log-linear form. Expressing the continuous variables in natural $\operatorname{logs}$ and including theatre fixed effects $\left(c_{j}\right)$ that control for unobservable characteristics of theatres which do not change over time, the full empirical model is given by following equation:

$$
\begin{aligned}
\log A T T_{j t}= & \log \alpha_{o}+c_{j}+\alpha_{1} \log P_{j t}+\alpha_{2} \log I_{j t}+\alpha_{3} \log C_{j t}+\alpha_{4} G_{j t} \\
& +\alpha_{5} \log D E C_{j t}+\alpha_{6} \log A R T_{j t}+\alpha_{7} D I F_{j t}+u_{j t},
\end{aligned}
$$

where the $\alpha_{k}$ 's are parameters to be estimated, $c_{j}$ are theatre specific effects and $u_{j t}$ is the error term. The dependent variable is the total number of visitors, $A T T_{j t}$, attending the performances in theatre $j$ and season $t$. This measure includes aggregated tickets sales at the theatre's own location but it does not include attendance at guest performances. Furthermore, this measure consists of visitors attending drama performances, musical theatre (opera, operetta, musicals), and also ballet and classical concerts. The first two important determinants of theatre attendance are: theatre admission price, $P_{j t}$, which should have a negative effect on attendance and disposable income per capita, $I_{j t}$, which should have a positive effect. The total capacity variable, $C_{j t}$, is the number of seats in a theatre multiplied by the number of all performances. It is assumed that theatre attendance is constrained by total theatre capacity and it depends positively on it.

\footnotetext{
${ }^{3}$ Both in Austria and Switzerland there are also small independent companies (Freie Gruppen) which operate with no guarantee of receiving public subsidies.
} 
Given the available data, four output characteristics are also included in the model which describe objective quality of the artistic performances. These are: a guest performances index, $G_{j t}$, the yearly outlay on décor and costumes, $D E C_{j t}$, the number of artists employed in theatre $j$ and season $t, A R T_{j t}$, and the differentiation index, $D I F_{t}$. The first two of these variables should have a positive impact on theatre attendance but there is no reason to expect any particular sign for the coefficients of $A R T_{j t}$ and $D I F_{j t}$. Furthermore, the guest performances index, $G_{j t}$, and the differentiation index, $D I F_{j t}$, are not expressed in natural logs as they represent a percentage ratio and a discrete variable, respectively.

The description of all variables included in equation (1) is provided in Table 3 in the Appendix. However, the construction of some variables requires more explanation. In order to calculate income per capita, $I_{j t}$, theatre markets are constructed using the spatial weight matrix approach of Zieba (2009). The market for theatre $j$ is defined as $M_{j}$ with $\left(m_{i k}\right)_{j}$ elements grouping the regions into the relevant theatre market. Thus, disposable income per capita for theatre $j$ and season $t$ is defined as: $I_{j t}=\left(M_{j} \cdot Y d_{i t}\right) /\left(M_{j} \cdot P O P_{i t}\right)$, where $Y d_{i t}$ and $P O P_{i t}$ are the disposable income and population of the relevant region $i$ and period $t$, respectively. To define the theatre markets, the federal regions in Austria and the cantons in Switzerland are used as geographical units. According to this, the market for an Austrian theatre is defined within the federal region in which theatre $j$ is located. In other words, the elements of matrix $M_{j}$ take values $\left(m_{i k}\right)_{j}=1$ in the federal region in which theatre $j$ is located. The cantons in Switzerland are geographically much smaller regions than the federal regions in Austria and hence including neighbouring cantons and their neighbours in the relevant market is appropriate. Thus, the elements of matrix $M_{j}$ take values $\left(m_{i k}\right)_{j}=1$ in the canton in which theatre $j$ is located as well as in its neighbouring cantons and border-sharing cantons of neighbours.

With regard to the four output characteristics variables, the guest performances index $\left(G_{j t}\right)$ is calculated, in line with Zieba (2009) and similarly to O'Hagan and Zieba (2010) as the ratio of guest performances divided by all performances staged by theatre $j$ in season $t$. The higher this ratio the higher the reputation perhaps of the theatre in question and the greater the impact on attendance at own location. The output characteristics variable, $D E C_{j t}$, is used to define the technical level of stage design and costumes. The output characteristics variable cast size, $A R T_{j t}$, is the number of artists employed at theatre $j$ in season $t$. This measure includes the number of solo performers, dancers, opera singers, choir, ballet and orchestra members. The number of artists indicates the scale of production, given theatre capacity. This variable could not be included in the econometric model for French-speaking Swiss theatres (nor in the model for all Swiss theatres). As mentioned earlier, theatres in French-speaking Switzerland do not have a permanently employed artistic ensemble and hence the data on artists are often not reported for these theatres in Theaterstatistik. The last output characteristics variable is the differentiation index, $D I F_{j t}$, which is a sum of indicator variables, each coded 1 if the specific art genre was performed by theatre $j$ in season $t$ and 0 otherwise.

The model given by equation (1) will be fitted to unbalanced panel data. For both Austrian and Swiss theatres the data set represents a long-panel where the number of time periods $(T)$ is large relative to the number of theatres $(N)$. In this case, it is very likely that the error term is first-order autoregressive. Therefore, a model for serial correlation 
in the error for the long-panel case is specified. The statistical noise term, $u_{j t}$ given in equation (1) is adjusted for both Austrian and Swiss theatres according to the Markov first-order autoregressive scheme $\operatorname{AR}(1)$ so that $u_{j t}=\rho \cdot u_{j t-1}+\varepsilon_{j t}$, where $\rho$ is the first-order coefficient of autocorrelation at lag 1.

The fixed-effects estimator provides consistent estimates of the coefficients of the time-varying regressors under a limited form of endogeneity. This means that the regressors in equation (1) may be correlated with the fixed effects, $c_{j}$, but not with the error term, $u_{j t}$. The issue of endogeneity in estimating demand for German theatre was discussed at length by O'Hagan and Zieba (2010). They applied a dynamic difference GMM estimator in order to correct for possible endogeneity bias. Their results varied little from those using a fixed-effects estimator, thereby rejecting the possibility of any serious endogeneity problems. As such, in this paper only a fixed-effects model is applied.

\section{Empirical Results}

\subsection{Descriptive Statistics}

Figures 1, 2 and 3 provide some broad trends of the variables used to estimate the model. In Figure 1 total attendance in Switzerland decreased from 1.6 million in 1979/80 to 1.4 million visitors in 2004/05. For Austrian theatres total attendance decreased also, albeit from a higher base, from 3.9 million in 1969/70 to 3.6 million in 2004/05. It is interesting to note that total theatre attendance did not decline significantly in either Austria or Switzerland as happened in Germany (see O'Hagan and Zieba, 2010). Total capacity exceeded total attendance by a wide margin in each year and on average theatre capacity is also much greater than the total attendance (see also Table 1). Furthermore, both real income and real price increased significantly over the period (Figure 2), each expected to have opposing effects on attendance. These variables showed some fluctuation around trend, in each country, but the trend was clearly upward over the whole period.
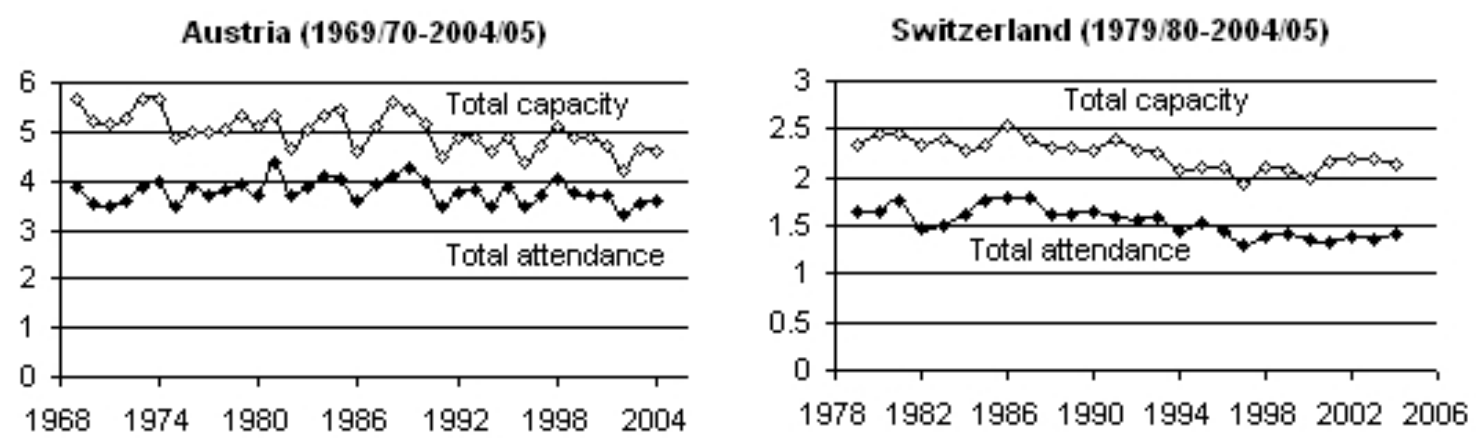

Figure 1: Total Theatre Attendance and Capacity

Figure 3 outlines total employment of artists in theatre in each country. Again there was some fluctuation from year to year but overall there was no discernible trend. Employment levels increased only slightly reflecting the fact perhaps that total attendance remained fairly steady in both countries. 
Austria (1969/70-2004/05)

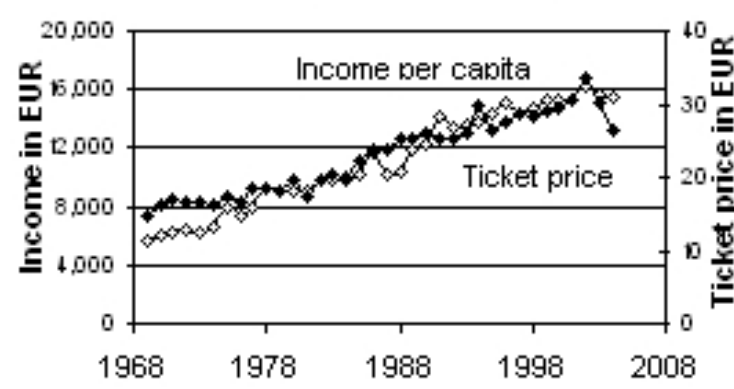

Switzerland (1979/80-2004/05)

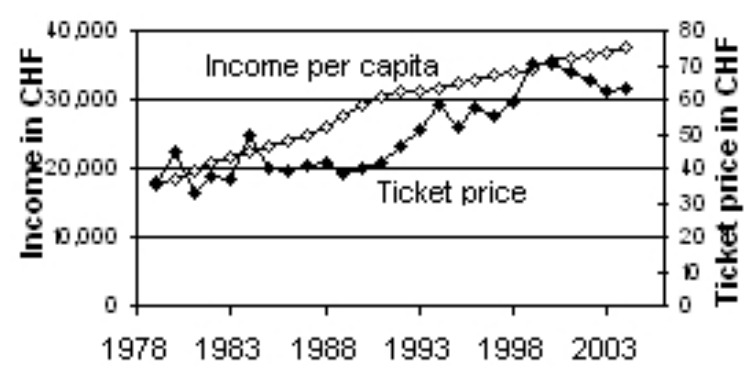

Figure 2: Real Income and Ticket Price

Austria (1969/70-2004/05)

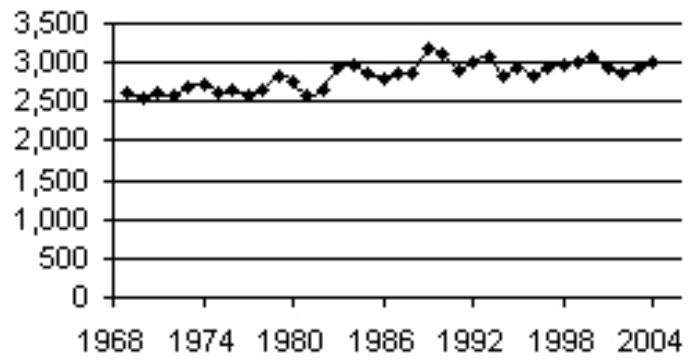

Switzerland (1969/70-2004/05)

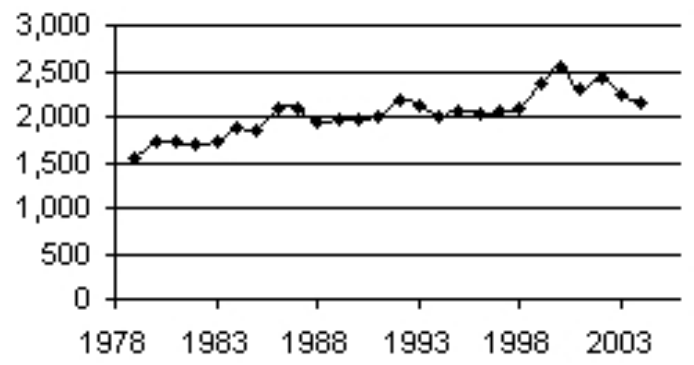

Figure 3: Total Number of Artists Employed

Table 1 provides the summary statistics for the main variables used in the regressions. As can be seen the standard deviations are in most cases high in relation to the means, indicating that there was considerable variation in the measured variables and hence that the data provide a robust source with which to test the various hypotheses.

\subsection{Model Estimates}

The estimation results for the fixed-effects models are presented in Table 2. The results are presented in column (1) for Austrian theatres and in column (2) for all Swiss theatres. Furthermore, as discussed earlier, the results for Swiss theatres are also analysed separately for two sub-samples: German-speaking and French-speaking theatres and they are presented in columns (3) and (4) of Table 2, respectively.

In each case a Hausman specification test validates the use of the fixed-effects estimator while an F-test indicates that a pooled model using OLS would produce inconsistent estimates. Serial correlation is a common problem where the time variation in the data is dominant over the cross-sectional variation. A test for serial correlation in the errors (Wooldridge, 2002) is performed and the null hypothesis that the residuals from the regression of first-differenced variables have an autocorrelation coefficient of -0.5 is rejected at the 1 per cent level for both Austrian and Swiss theatres. Thus, as discussed in Section 3, we correct for serial correlation by first removing the AR(1) component from 
Table 1: Summary statistics

\begin{tabular}{|l|rrrr|}
\hline & Austrian Theatres & Swiss Theatres & German-Speaking & French-Speaking \\
& & & Swiss Theatres & Swiss Theatres \\
\hline & $(1)$ & $(2)$ & $(3)$ & $(4)$ \\
\hline Attendance & 248951 & 90447 & 115021 & 52380 \\
$A T T_{j t}$ & $(163650)$ & $(77403)$ & $(85592)$ & $(39441)$ \\
\hline Ticket price & 22.90 & 51.04 & 47.62 & 56.48 \\
$P_{j t}$ & $(12.56)$ & $(37.26)$ & $(34.10)$ & $(41.31)$ \\
\hline Income per capita & 11048 & 33394 & 34046 & 32384 \\
$I_{j t}$ & $(11709)$ & $(2855)$ & $(3084)$ & $(2098)$ \\
\hline Total capacity & 330110 & 132431 & 171684 & 71623 \\
$C_{j t}$ & $(199697)$ & $(117903)$ & $(131888)$ & $(49389)$ \\
\hline Guest index & 0.06 & 0.12 & 0.09 & 0.16 \\
$G_{j t}$ & $(0.11)$ & $(0.17)$ & $(0.15)$ & $(0.19)$ \\
\hline Décor and costumes & 4577 & 934878 & 970537 & 877041 \\
$D E C_{j t}$ & $(5626)$ & $(1211876)$ & $(1013888)$ & $(1479415)$ \\
\hline Cast size & 186.9 & - & 154.2 & - \\
$A R T_{j t}$ & $(136.4)$ & - & $(148.8)$ & - \\
\hline Differentiation index & 2.9 & 2.7 & 3.1 & 2.1 \\
$D I F_{j t}$ & $(1.4)$ & $(1.6)$ & $(1.6)$ & $(1.4)$ \\
\hline
\end{tabular}

Mean values. Standard deviation in parentheses. * Nominal values for variables $P_{j t}, I_{j t}$ and $D E C_{j t}$ are converted into real values for the year 2000 and expressed in EUR for Austria and in CHF for Switzerland.

the error term before fitting the fixed-effects model. ${ }^{4}$ Furthermore, the log-linear model was chosen since a substantially better statistical fit was obtained through the use of the logarithmic transformation of all continuous variables as compared to a simple linear function or semi-log specification. The logarithmic transformation has also the advantage that the estimates of price $\left(P_{j t}\right)$ and income $\left(I_{j t}\right)$ variables can be interpreted as direct partial elasticities.

The adjusted R-squared figures in Table 2 are very high, indicating that the overall explanatory power of the included variables is good. The estimates of price elasticity $\left(P_{j t}\right)$ are negative, as expected, highly significant and range from -0.2 for all Swiss theatres to -0.5 for Austrian theatres. The estimates of income elasticity $\left(I_{j t}\right)$ are positive and also highly significant. The coefficient for income elasticity ranges from 0.3 for all Swiss theatres to 0.7 for Austrian theatres, and hence is smaller than one. It should also be noted that both price and income elasticities are much higher for German-speaking theatres than for French-speaking theatres in Switzerland. For the latter theatres the income effect is only 0.2 but it still outweighs the negative price effect.

The coefficient of total theatre capacity, $C_{j t}$ is also greater than zero and it almost shows no variation between the countries and between different groups of theatres in Switzerland. In relation to output characteristics, the guest performances index $\left(G_{j t}\right)$ is positive but significant only at the 10 per cent level for Austrian theatres. For Swiss theatres the index is negative and not significant. Thus, in contrast to Germany (see O'Hagan

\footnotetext{
${ }^{4}$ This model is estimated in STATA 10 software using xtregar, fe command.
} 
Table 2: Estimation Results for Fixed-Effects Models with AR(1) Disturbance

\begin{tabular}{|c|c|c|c|c|}
\hline \multirow[t]{2}{*}{$\begin{array}{l}\text { Dependent variable: } \\
\log A T T_{j t}\end{array}$} & Austrian Theatres & Swiss theatres & $\begin{array}{r}\text { German-speaking } \\
\text { Swiss theatres }\end{array}$ & $\begin{array}{r}\text { French-speaking } \\
\text { Swiss theatres }\end{array}$ \\
\hline & (1) & $(2)$ & (3) & $(4)$ \\
\hline \multirow[t]{2}{*}{ Constant } & $0.613 * * *$ & $0.495 * * *$ & -0.024 & $0.304 * * *$ \\
\hline & $(0.057)$ & $(0.061)$ & $(0.131)$ & $(0.080)$ \\
\hline \multirow{2}{*}{$\begin{array}{l}\text { Ticket price } \\
\log P_{j t}\end{array}$} & $-0.529 * * *$ & $-0.225^{* * *}$ & $-0.477 * * *$ & $-0.121 * *$ \\
\hline & $(0.029)$ & $(0.030)$ & $(0.040)$ & $(0.048)$ \\
\hline \multirow{2}{*}{$\begin{array}{l}\text { Income per capita } \\
\log I_{j t}\end{array}$} & $0.710 * * *$ & $0.337 * * *$ & $0.782 * * *$ & $0.190^{* * *}$ \\
\hline & $(0.052)$ & $(0.046)$ & $(0.074)$ & $(0.067)$ \\
\hline \multirow{2}{*}{$\begin{array}{l}\text { Total capacity } \\
\log C_{j t}\end{array}$} & $0.527 * * *$ & $0.623 * * *$ & $0.334 * * *$ & $0.727 * * *$ \\
\hline & $(0.031)$ & $(0.035)$ & $(0.049)$ & $(0.052)$ \\
\hline \multirow{2}{*}{$\begin{array}{l}\text { Guest index } \\
G_{j t}\end{array}$} & $0.163^{*}$ & -0.099 & -0.162 & -0.163 \\
\hline & $(0.092)$ & $(0.081)$ & $(0.142)$ & $(0.113)$ \\
\hline \multirow{2}{*}{$\begin{array}{l}\text { Decor and costumes } \\
\log D E C_{j t}\end{array}$} & $0.018^{*}$ & $0.065 * * *$ & 0.025 & $0.070^{* * *}$ \\
\hline & $(0.010)$ & $(0.018)$ & $(0.021)$ & $(0.029)$ \\
\hline \multirow{2}{*}{$\begin{array}{l}\text { Cast size } \\
\log A R T_{j t}\end{array}$} & $0.037 *$ & - & $0.172 * * *$ & - \\
\hline & $(0.021)$ & - & $(0.036)$ & - \\
\hline \multirow{2}{*}{$\begin{array}{l}\text { Differentiation index } \\
D I F_{j t}\end{array}$} & -0.003 & -0.022 & -0.018 & -0.024 \\
\hline & $(0.008)$ & $(0.014)$ & $(0.014)$ & $(0.027)$ \\
\hline Number of observations & 525 & 405 & 253 & 151 \\
\hline Number of theatres & 20 & 25 & 12 & 13 \\
\hline \multirow{2}{*}{$\begin{array}{l}\text { Number of time periods } \\
R^{2}\end{array}$} & 36 & 26 & 26 & 26 \\
\hline & 0.87 & 0.96 & 0.85 & 0.96 \\
\hline \multirow{2}{*}{$\begin{array}{l}\text { F-test for existence } \\
\text { of individual effects }\end{array}$} & $14.61 * * *$ & $5.74 * * *$ & $12.37 * * *$ & $3.11^{* * *}$ \\
\hline & $(19,498)$ & $(24,374)$ & $(11,234)$ & $(12,132)$ \\
\hline \multirow{2}{*}{$\begin{array}{l}\text { Hausman Test } \\
\text { Chi-Squared }\end{array}$} & & & & \\
\hline & $64.76 * * *$ & $37.1 * * *$ & $24.75 * * *$ & $11.21 *$ \\
\hline
\end{tabular}

Standard errors in parentheses. *** indicate significance at the 1 per cent level. ** and * indicate significance at the 5 and 10 per cent level respectively. The variable $\log A R T_{j t}$ is not included in column (2) and (4) for all Swiss theatres and French-speaking Swiss theatres (see Section 3 for explanation).

and Zieba, 2010), this quality variable does not seem to have a significant effect on theatre attendance in Austria and Switzerland. This may be partly due to the fact that the dependent variable used in this study includes only the number of visitors attending performances at the theatre's own venues and it does not include guest attendance of the theatre ensembles at other locations. Furthermore, in contrast to German theatres, not all Austrian and Swiss theatres tour and play guest performances every season. In fact, the average share of guest performances in all performances is low for these theatres with the exception of French-speaking Swiss theatres (see Table 1) whereas in the case of Germany this share amounted on average to 16 per cent (see also Zieba, 2009).

Nevertheless, similarly to O'Hagan and Zieba (2010), the coefficient of $D E C_{j t}$ (outlay on décor and costumes) is always positive for both Austrian and Swiss theatres and mostly statistically significant. The coefficient of the variable, $A R T_{j t}$, is also positive and 
significant, implying that the greater the cast size the higher the attendance. The coefficient of the product differentiation index, $D I F_{j t}$ is not significant and hence its sign is of little consequence, as it was the case for German theatres. ${ }^{5}$ The latter result indicates that the differentiation of artistic product with regard to the art genre has no influence on theatre attendance.

\section{Conclusion}

This study provides further empirical insights into the effects of the determinants of demand for theatre using a novel panel data set for Austrian and Swiss theatres. The results are significant and confirm the key hypotheses concerning the various influences on theatre attendance discussed earlier.

Price and income are highly significant determinants of theatre attendance in both countries, but there is some variation in these estimates. However, the notable thing is that in all cases the demand for theatre tickets is price-inelastic. Thus, increasing ticket price by 10 per cent will decrease theatre attendance by only 5 per cent in Austria and 2 per cent in Switzerland. The estimated income elasticities, are also in all cases positive but below one. These results are in line with the findings of other studies (see Moore, 1966; Gapinski, 1984, 1986; Werck and Heyndels, 2007; O'Hagan and Zieba, 2010). Income elasticity though is the net effect of two offsetting factors, price of leisure time and full-income, and Withers (1980) and Zieba (2009) have shown that the elasticity with respect to the latter is in fact well above one.

Furthermore, the effects of theatre capacity as one would expect impact strongly and positively on attendance. Capacity varies hugely across theatres but not over time, and this would have a large impact on the variation across theatres at a point in time, even if theatre capacity is rarely reached.

The results with regard to output characteristics confirm mostly the findings for German theatre (see O'Hagan and Zieba, 2010). The only exception applies to the guest performances index which does not have an important effect on attendance at the theatre's own location. As discussed earlier, this discrepancy in the results holds especially for Swiss theatres and it relates mainly to a slightly different measure of the dependent variable used in this study. Furthermore, the differentiation index is not significant for both Austrian and Swiss theatres and its impact on attendance was also very small for German theatres. Nevertheless, the other two output characteristics variables which describe artistic quality have a positive and significant effect on theatre attendance. In relation to average expenditure on décor and costumes, it might be that the higher this expenditure the higher the attendance, but the larger resulting revenue might not justify the increased outlay. The same is true with regard to the cast size.

The most reassuring findings of this study then relate to price and income elasticities. Despite the difficulties of measuring these effects in relation to theatre attendance, this study confirms again that price and income do matter but with elasticities well below one in absolute terms. It seems that with rising incomes the price of leisure time also increases

\footnotetext{
${ }^{5}$ For German theatres the estimate of the differentiation index was significant for one time period only (depending on the econometric model applied) and its magnitude was also very low.
} 
and hence to a low net income effect on attendance. Furthermore, the findings of a priceinelastic demand suggest that the artistic quality rather than the price reductions, may offer a more effective way of attracting visitors.

\section{Appendix}

Table 3: Description of Variables and Data Sources for Austrian and Swiss theatres*

\begin{tabular}{|c|c|}
\hline Variable & Description \\
\hline Attendance, $A T T_{j t}$ & $\begin{array}{l}\text { It is the total number of tickets sold at the theatre's own location, in- } \\
\text { cluding the number of visitors attending drama performances, musical } \\
\text { theatre (opera, operetta, musicals) and also ballet and classical con- } \\
\text { certs. This measure also includes attendance at performances staged by } \\
\text { foreign ensembles but it does not include attendance at guest perfor- } \\
\text { mances. }\end{array}$ \\
\hline Ticket price, $P_{j t}$ & $\begin{array}{l}\text { The operating theatre revenues divided by the number of tickets sold } \\
\text { and adjusted using the consumer price index (CPI). }\end{array}$ \\
\hline $\begin{array}{l}\text { Total capacity of } \\
\text { theatre, } C_{j t}\end{array}$ & $\begin{array}{l}\text { The number of seats multiplied by the number of performances. It was } \\
\text { calculated separately for each venue available in a theatre and summed } \\
\text { up to obtain the total capacity. }\end{array}$ \\
\hline $\begin{array}{l}\text { Disposable income } \\
\text { per capita, } \mathrm{I}_{j t}\end{array}$ & $\begin{array}{l}\text { It is disposable income }\left(Y d_{i t}\right) \text { of the population in the region } i \text {, divided } \\
\text { by the total population of the relevant region }\left(P O P_{i t}\right) \text { and adjusted } \\
\text { using the spatial weight matrix for each country, and deflated with CPI } \\
\text { (see also Section } 3 \text { and Zieba, 2009). The regional data on income and } \\
\text { population were obtained for federal regions in Austria and cantons in } \\
\text { Switzerland.** }\end{array}$ \\
\hline Guest index, $G_{j t}$ & $\begin{array}{l}\text { The number of guest performances divided by the number of all perfor- } \\
\text { mances. }\end{array}$ \\
\hline $\begin{array}{l}\text { Outlay on décor and } \\
\text { costumes, } D E C_{j t}\end{array}$ & $\begin{array}{l}\text { Total yearly expenses on décor and costumes deflated using the whole } \\
\text { sale price index (WHI) for Austria and the implicit price deflator (IPD) } \\
\text { for Switzerland. }\end{array}$ \\
\hline $\begin{array}{l}\text { Cast size, } A R T_{j t}, \\
\text { (Austrian and } \\
\text { German-speaking } \\
\text { Swiss theatres only) }\end{array}$ & $\begin{array}{l}\text { It is the total number of artists including artistic management, singers, } \\
\text { dancers, actors, musicians, orchestra and choir members and guest } \\
\text { artists. The number of guest artists is weighted by a factor of } 0.5 \text { as } \\
\text { they are employed on a part-time basis. }\end{array}$ \\
\hline $\begin{array}{l}\text { Product differentia- } \\
\text { tion index, } D I F_{j t}\end{array}$ & $\begin{array}{l}\text { It is the sum of dummy variables } \sum_{k}^{K} D_{k j t} \text {. The indicator variable } \\
D_{k j t} \text { takes a value of } 1 \text { if the specific art form } k \text { was performed and } 0 \\
\text { otherwise. Five dummies are considered: } 1 \text { ) opera, 2) operetta, musical, } \\
\text { 3) drama and youth theatre, 4) ballet, 5) concerts and others. }\end{array}$ \\
\hline \multicolumn{2}{|c|}{$\begin{array}{l}\text { * Main data sources: Theaterstatistik, Deutscher Bühnenverein, 1969/70 - 2004/05, Tables } \\
\text { from } 1 \text { to } 5 \text { of Appendix } 1 \text { (Austrian theatres), Theaterstatistik, Deutscher Bühnenverein, } \\
\text { 1979/80 - 2004/05, Tables from } 1 \text { to } 5 \text { of Appendix } 2 \text { (Swiss theatres). } \\
\text { ** Data sources on income, population and indices: 'Statistik Austria', Federal Statistics } \\
\text { Office, ISIS Data Base (Intergriertes Statistisches Informationssystem); 'Statistik Schweiz', } \\
\text { National Accounts of Federal Statistics Office, www.bfs.admin.ch/bfs/portal/de/ } \\
\text { index/themen.html; EcoWin Pro Database. (The exact data are available on request.) }\end{array}$} \\
\hline
\end{tabular}




\section{References}

Gapinski, J. (1984). The economics of performing Shakespeare. American Economic Review, 74, 458-466.

Gapinski, J. (1986). The lively arts as substitutes for the lively arts. American Economic Review, 76, 20-25.

Gruber, K., and Köppl, R. (1998). The theatre system of Austria. In H. van Maanen and S. Wilmer (Eds.), Theatre Worlds in Motion. Structures, Politics and Developments in the countries of Western Europe (p. 37-73). Amsterdam.

Kotte, A. (1998). The theatre system of Switzerland. In H. van Maanen and S. Wilmer (Eds.), Theatre Worlds in Motion. Structures, Politics and Developments in the countries of Western Europe (p. 619-667). Amsterdam.

Moore, T. (1966). The demand for Broadway theatre tickets. Review of Economics and Statistics, 48, 79-87.

O'Hagan, J., and Zieba, M. (2010). Output characteristics and other determinants of theatre attendance - An econometric analysis of German data. Applied Economics Quarterly, 56, 147-174.

Werck, K., and Heyndels, B. (2007). Programmatic choices and the demand for theatre: the case of Flemish theatres. Journal of Cultural Economics, 31, 25-41.

Withers, G. (1980). Unbalanced growth and the demand for performing arts: An econometric analysis. Southern Economic Journal, 46, 735-742.

Wooldridge, J. (2002). Econometric Analysis of Cross Section and Panel Data. London: MIT Press.

Zieba, M. (2009). Full-income and price elasticities of demand for German public theatre. Journal of Cultural Economics, 33, 85-108.

Author's address:

Marta Zieba

Department of Economics

Trinity College Dublin

College Green

Dublin 2, Ireland

E-Mail: ziebam@tcd.ie 